\title{
SUBJECT-SPECIFIC VOCABULARY AND ITS STRATIFICATION: THE CASE OF AVIATION ENGLISH
}

\author{
Inna Fainman \\ Flight Academy of National Aviation University, Kropyvnystkyi, Ukraine \\ fineinna@yahoo.com \\ Yevheniia Tokar \\ Flight Academy of National Aviation University, Kropyvnystkyi, Ukraine \\ finejenya@hotmail.com
}

\begin{abstract}
The primary focus of the paper is on providing basic characteristics of subject-specific vocabulary classes and stratifying Aviation English vocabulary. Aviation English which serves for professional communication uses discipline-specific vocabulary which defines and transfers professional knowledge. The first part of the paper investigates the most commonly distinguished classes of lexis within the subject-specific vocabulary. They are stated to be terms, semi-technical vocabulary, professionalisms, professional slang and jargon, nomenclature names. Each class is presented in more detail in the second part of the paper. Peculiar features of every class of items are determined in order to enable differentiation from all other groups of lexis. The third part focuses on Aviation English vocabulary stratification. Taking into account the research already existing on the issue and having conducted its critical analysis as well as having thoroughly studied Aviation lexicographical issues and electronic-based aviation word lists, the authors present their view on Aviation English vocabulary stratification providing examples of lexis within each group. 6 groups of lexical items in Aviation English vocabulary are distinguished by the authors: 1) basic aviation concepts; 2) general scientific and interdisciplinary terms; 3) semi-technical vocabulary; 4) nomenclature names (nomens); 5) codes; 6) professional slang and jargon.
\end{abstract}

Keywords: Aviation English; subject-specific vocabulary; vocabulary stratification; terms.

\section{Introduction}

Modern professional activity is based mainly on participants' interaction which presupposes verbal oral as well as written information exchange. Different professional spheres have their specific subsets of language which provide communication of its specialists and transfer of special professional knowledge. Subject-specific vocabulary is the core of such a language subset which defines, forms and transfers professional knowledge about objects, processes and phenomena of professional activity. It reflects scientific, technical, economic and social knowledge and is contrasted to general vocabulary. However, the boundary between these two classes of vocabulary is rather vague since one glossary item can be used both in everyday general communication as well as in a special sphere of knowledge and activity. Besides, an item of general vocabulary may transfer to special one either as a whole or in one of its meanings and become a term as well as a specific vocabulary item can turn into a general one (Shelov \& Leichik, 2012, p. 3).

Subject-specific vocabulary has long been an object of numerous linguistic (Griniev, 1993; Shelov \& Leichik, 2012, Dudley-Evans, 1998) etc.). The issues of subject-specific vocabulary classification, theoretic description of its basic classes and subclasses, studying their similarities and differences are of great interest to linguists. There is a variety of views on subject-specific lexis, its classification, but there is still lack of research regarding Aviation English vocabulary stratification.

The objective of this paper is to present Aviation English vocabulary stratification and define classes of Aviation English lexical items on the basis of their semantic and functional characteristics.

\section{Method}

To fully understand the linguistic features of Aviation English vocabulary and work out its stratification we have thoroughly studied the already existing linguistic research on the issues of LSP vocabulary, the variety of its classes and categories. We have also carried out a detailed review of scientific studies on aviation communication, Aviation English, aviation vocabulary.

Our research is based on using classification and structuring method to explore aviation vocabulary as a linguistic object. Semantic characteristics, as well as functional features of the lexical units in aviation domain, have been chosen to be the criteria for stratifying Aviation English vocabulary. Aviation lexicographical issues (Dictionary of Aviation, 2005; An Illustrated Dictionary of Aviation, Dictionary of Aeronautical Terms) and electronic-based aviation word lists (http://www.aviation-terms.com) served as a source for selecting the items to be studied. To investigate the functional aspects of vocabulary units the linguistic analysis of aviation discourse has been conducted on the basis of the current ICAO documents, 
17 articles on aviation and 30 pieces of recordings with pilot-ATC communication and air transportation briefings. In general, the amount of the lexical material under study reaches 2350 aviation vocabulary units.

\section{Results and discussion}

Aviation English has its specialised vocabulary which reflects scientific and professional knowledge in its contents. Its vocabulary is organised as a special functional system, including subsystems for specific areas of professional activity, has its own holistic structure and is restricted to the sphere of aviation.

Modern aviation vocabulary is subject to the general law of language: its formation is a complex of quantitative growth and qualitative change, it is a system in motion. It covers the names of aviation concepts that appeared before, derives from other languages those elements which it lacks, adding new, those that relate to concepts that have just emerged (Karaban, 2004, p. 17).

Our study of the semantic characteristics of the selected lexical units and their functioning in the aviation discourse gave ground to distinguishing 6 groups of lexical items in Aviation English vocabulary: 1) basic aviation concepts; 2) general scientific and interdisciplinary terms; 3) semi-technical vocabulary; 4) nomenclature names (nomens); 5) codes; 6) professional slang and jargon.

\section{Definition}

According to Coxhead (2017) subject-specific (or specialised) vocabulary is one of the names that LSP vocabulary receives from one research study to another. In general, the term "subject-specific vocabulary" is used to describe lexical items which tend to occur mostly in one discipline and not in others (Coxhead, 2017, p. 64). As stated in the reference dictionary of linguistic terms, "subject-specific vocabulary consists of words or collocations, which name objects and notions belonging to certain spheres of employment and are not commonly used" (Rozental \& Telenkova, 2001, p. 522). In other words, subject-specific vocabulary is a group of words, which indicate scientific notions and are stable reproducible elements in the system of domain-specific knowledge, occupying certain classificatory positions.

\section{Categories/classes of subject-specific vocabulary}

Analysis of linguistic research gave us ground to state that defined classes of lexical units that comprise subject-specific vocabulary are numerous, going with some linguists as far as 10 .

According to Dudley-Evans \& John (1998) making a clear-cut division of vocabulary into two areas is applied specifically to the language for specific purposes (LSP) vocabulary (p. 83). The first group of words proposed by Dudley-Evans and John (1998) can be named semi-technical vocabulary and includes general language vocabulary, having a higher frequency of occurrence in specialist discussion, whereas the second area consists of strictly technical vocabulary items with specific and highly restricted meaning.

The other views on subject-specific vocabulary most commonly distinguish between 3 and 5 classes of lexis. Coxhead (2017) presents three types of specialised words: words of Greek or Latin origin, highly technical words and words used also in general English. Fraser (2012), for example, suggested that the specialised vocabulary might be divided into fully technical, lay technical, cryptotechnical and academic categories.

Fully technical vocabulary consists of words with meanings which are clearly technical; they are specific to the field and not likely to be known in general language. Cryptotechnical vocabulary consists of polysemous words (...) which could be said to be "cryptic" in that they have a technical meaning which may be obscure to a non-specialist. Lay-technical words, on the other hand, are those terms which are obviously technical, but whose basic meaning would, nevertheless, be understood by someone without specialist knowledge in the field. Academic vocabulary contains a large number of discourse-structuring words and words with an analytic or evaluative role (e.g. adequate, maintain, insufficient)" (p. 124).

The detailed study helped the authors define the categories of subject-specific vocabulary most commonly distinguished by different scholars on the basis of a variety of criteria. The most frequently mentioned groups of words within specific vocabulary include terms, semi-technical vocabulary, professionalisms, professional slang and jargon, nomenclature names. We would like to characterise them in order to take the analysis into account when stratifying Aviation English vocabulary.

\section{Terms}

All linguists consider terms (by English-speaking scholars often referred to as "technical vocabulary") to be the core of subject-specific vocabulary.

Every profession necessarily has its own terminology, without which its members cannot think or express themselves. To deprive them of such words would be to condemn them to inactivity. If one wished to 
kill a profession, to remove its cohesion and its strength, the most effective way would be to forbid the use of its characteristic language (Hudson, 1978, p. 1).

Tabanakova (2013) states that a term is a linguistic sign expressing special scientific notion and reflecting the place of this notion in the respective system of scientific notions, system of knowledge; i.e. a term is a sign brought into correlation not just with one special notion, but with a system of notions. This function defines a number of term features, namely narrow, confined sphere of usage, limited combinability with other words, accuracy, monosemy within one terminological system, consistency, avoiding synonyms and lack of emotional colouring (pp. 19-22).

The basic characteristics, which make it possible to differentiate terms in subject specific vocabulary, are denoted by Griniev(1993): 1) peculiarity of usage (each term belongs to a special sphere of knowledge); 2) function of notion designation; 3) definitive pattern (scientific definition); 4) accuracy of the meaning (which is provided by the definition); 5) contextual consistency (the meaning of the term is clear without context and barely depends on it); 6) stylistic neutrality; 7) esotericism (the exact meaning of the term is known only to the specialists); 8) nominative character (term is usually a noun or a word-combination based on the noun); 9) reproducibility in speech (which is important for word-combinations) (pp. 34-35).

Since general scientific terms belong to different areas, they are used more often and represent general assembly of notions of different sciences while special terms contain the main volume of knowledge of every specific science (Bugaienko \& Zhulikov, 2013, p. 35). With increasing interdisciplinarity, the demarcation lines between subject fields are becoming blurred, there is a considerable overlap. Consequently, terms cannot be fully isolated or protected within its subject field as a separate entity (Pearson, 1998, pp. 10-21).

\section{Semi-technical vocabulary}

Sub-technical or semi-technical vocabulary constitutes another layer of subject-specific vocabulary (Hutchinson \& Watchers, 1987; Dudley-Evans \& John, 1998; Baker, 1988). Baker (1988) points out that "subtechnical vocabulary covers a whole range of items which are neither highly technical and specific to a certain field of knowledge nor obviously general in the sense of being everyday words which are not used in a distinctive way in specialized texts" (p. 91). The scholar distinguishes 6 types of items which have been referred to as "subtechnical" by various linguists:

1) Items which express notions general in all or several specialised disciplines;

2) Items which have a specialised meaning in one or more disciplines in addition to a different meaning in general language;

3) Items which are not used in general language but which have different meanings in several specialised disciplines;

4) Items which are traditionally viewed as general language vocabulary which have restricted meanings in certain specialised disciplines;

5) General language items which are used, in preference to other semantically equivalent items, to describe or comment on technical processes and functions;

6) Items which are used in specialised texts to perform specific rhetorical functions. These are items which signal the writer's intentions or his evaluation of the material presented (Baker, 1988, p. 92).

Semi-technical vocabulary is the specialised use of general vocabulary in a given field. Therefore, the meaning of semi-technical vocabulary items is different from their meaning in general English (DudleyEvans \& John, 1998, p. 84) There is a similarity as the general language vocabulary appears in general English, while the technical vocabulary does not. In other words, General language vocabulary can be (in a micro scale) referred to as core, and technical as non-core vocabulary. Thus, features of terms and general language vocabulary overlap in the notion of "subtechnical" vocabulary.

\section{Professionalisms}

Another class of words constituting subject-specific vocabulary and differentiated by the majority of Soviet and post-Soviet scholars is called professionalisms. Their status is not fully defined by modern linguists. There are several points of view: 1) professionalisms are equated to terms; 2) diachronic differentiation, where professionalisms are considered to be a part of Middle Ages handcraft vocabulary; 3) differentiation on the basis of having non-normalised usage and functional-stylistic limits of usage in professionals' oral speech informally, as well as emotional-expressive connotation (Griniev, 1993).

We support such scientists as Dyakov, Kyiak \& Kudelko (2000), who state it "rational to differentiate professionalisms and terms which both constitute the notion of a special sublanguage" (p. 15). Having analysed numerous linguistic research Mykhailova (2001) presents a sufficiently full list of differences between these language units: 1) professionalisms are local shortened and simplified names, which duplicate 
terms, they are secondary according to their creation in relation to terms, which cannot have narrow local character; 2) terms are standardised lexical units, while professionalisms are semi-official; 3) terms function in oral and written communication of specialists of a definite sphere, professionalisms are used in spoken language; 4) professionalisms are characterised with connotations (evocative colouring); the term is deprived of any emotional and evocative colouring; 5) terms function in all spheres of scientific and industrial human activities, professionalisms are more often met in particular professions, crafts, trades; 6) terms may be created by means of native and foreign languages, professionalisms are created on the basis of native language, only in particular units foreign elements are found; 7) consistency is the most important feature of terminology, systemic connections between professionalisms are weaker, as they name separate objects and subnotions (p. 44-45).

Thus, professionalisms are semi-official stylistically labelled vocabulary units used in professional speech by a narrow circle of specialists for denoting familiar notions.

\section{Professional jargon or slang}

Professional jargon or slang is viewed either as a type of professionalisms (Griniev, 1993, p. 51; Serbinovskaya, 2009, p. 132) or completely differentiated from professionalisms (Shelov \& Leichik, 2012, p. 6; Bugaienko \& Zhulikov, 2013, p. 35) due to greater deviation from norms. Such deviation is more characteristic of jargon than of professionalisms and thus it represents a lower layer of LSP vocabulary.

According to Hudson (1978), jargon reflects particular occupation, is pretentious, with only a small meaning underneath it, and deliberately or accidentally mystifying (p. 3). "Such language is said to be more condensed and therefore time-saving, (...) it allows one professional to recognise another without waste of time and an indispensable means of keeping the public at a respectful distance" (Hudson, 1978, p. 6).

The professional jargon is the result of the job specialisation itself. It is well known only to professionals that use it daily and it may be rather confusing to newcomers or laymen. While terms are signifiers which are clearly equivalent to a concept, professional jargon and slang often use metaphors, simile and other stylistic resources.

Describing jargon and slang words Glaser (2000) states,

These informal words are typical of oral LSP communication in an everyday working environment; they do not designate a concept classified in a system or coined according to international patterns. Professional jargon is down-to-earth, drastic and shirt-sleeved. It may include colourful idiomatic expressions (p. 89).

\section{Nomenclature names}

Nomenclature names (nomens) as a layer of subject-specific vocabulary have long been discussed by a great number of linguists but still there is no single frame of mind on their essence and their relation to other layers of this system.

In our opinion the most complete list of nomens' characteristics has been worked out by Pavlova (2008) who pointed out that: 1) nomens are relevant to notions through terms and function in special communication; 2) they are proper names or take an intermediate position between terms and proper names; 3 ) they reflect classes of homogeneous objects; 4) they are a lower layer of special vocabulary in that sense that their understanding is impossible without interrelationship with other terminological units; 5) nomens are intensively nominative and conventional resulting from artificial naming intended for identifying special human activity; 6) nomens are characterised by notional derivation and secondariness; 7) nomenclature are on the periphery of the corresponding term system unlike terms, which belong to its core; 8) nomens are not fixed in dictionaries and exist only in the sphere of functioning; 9) a nomen which characterises an object is accorded with corresponding description which has features of this object while a term is accorded with definition which reflects notion's characteristic features (p. 53).

\section{Aviation English Vocabulary Stratification}

The above mentioned general characteristic of subject-specific vocabulary classes gave us the basis for defining Aviation English vocabulary layers. According to Moder (2013), "Aviation English is a term for the highly specialised language and interactional sequences used by pilots, air traffic controllers, and other aviation professionals. Like other areas of language for specific purposes (LSP), aviation English focuses on the particular pronunciation, vocabulary, grammatical structures, and discourse styles that are commonly used by practitioners in specific work-related contexts"(p. 227).

We found out that it is of high interest to the linguistics researchers researchers (Wang, 2011; Asmukovich, 2011; Kopecka, 2017) to analyse, classify and describe what lexical items Aviation English vocabulary actually includes and is composed of. 
Kopecka (2017) states,

[a] distinction needs to be drawn between at least 3 subgroups of aviation vocabulary. The first subgroup of vocabulary items belonging to aviation LSP includes words used only by professionals in aviation and aeronautics. All of the words assigned to this group are not known to and not understood by laypeople. These lexical items usually refer to pieces of equipment, activities, actions as well as other strictly technical phenomena, hence being irrelevant to everyday context, e.g. canard, high-lift device. The second subgroup of aviation vocabulary also includes words used by professionals and similarly the words assigned to the second group are not known to laypeople. But unlike the vocabulary in the first subgroup, words in the second subgroup appear in less formal situations, frequently in oral communication and may be referred to as aviation slang. The third group includes words used by professionals in professional communication, but at the same time these words belong to the lexical repertoire, at least passive, of lay people, e.g. fuselage, black box, aisle (pp. 203-204).

Having analysed more than 2000 vocabulary entries and functioning of the lexical items in the aviation texts and actual air speech recordings we tend to distinguish 6 classes of Aviation English vocabulary.

1. Basic aviation concepts that are the basis for the development of the technical means of aviation and the basis for their application: the terms of aerodynamics, theory of mechanisms and machines, the theory of engines, air navigation, etc (aerodynamic forces, aerodynamic resistance, lift, artificial horizon).

2. General scientific and interdisciplinary terms that contain a large amount of information. The terms of broad semantics characterised by a high degree of abstraction, they are part of a group of general technical, general scientific and intersectional terms and show their basic constitutive, nominative, classification and orientational properties. E.g. gravity, angle, adjust, distance.

3. Semi-technical vocabulary where an item has a different meaning in aviation from that in general usage (apron, separation, pushback, climb, maintain, taxi).

4. Nomenclature names (nomens) - a broad bulk of vocabulary intended to denote particular concepts that correspond to brands, series, models, modifications and other uniform series of objects ( $T u-204, T u-204-$ 100, Tu-204-200 aircraft). Nomens consist of two parts: actually from the generic term and nomenclature index syntactically subordinate to it. In general, nomens replace a detailed description of private notions (object), providing with information about the named object in a list of distinctive characteristics, or without a list of features and require index nomenclature to be decoded.

5. "Codes" or special lexical items that due to their brevity convey the idea which would take much more lexical effort to be transmitted, thus serving as a special "code" the meaning of which is understood by the representatives of the aviation community in much deeper sense than one lexical unit usually can have. E.g., to convey the meaning of consent and meaning "I have received all of your last transmission", the word Roger is used. Pan means that there is an urgent emergency situation on board (Pan. Medical. Require ambulance on landing), and Mayday is used to refer to a situation that qualifies as a calamity (Mayday, Mayday, Mayday Fire in the baggage compartment). In addition, radio exchange is characterised by the use of Q-codes, that do not have to be confused with abbreviations, because they are not a result of reduction, but belong to the system of three-letter codes used in radio communications. In particular, the following applications were accepted in aviation: $Q N H$ - atmospheric pressure at the average sea level, $Q F E$ atmospheric pressure at the aerodrome level, $Q D M$ - magnetic course.

6. Professional jargon and slang, which, as the most distant ones from the standard (norms), form the boundary class of special vocabulary of the aviation sphere. They are short, have a spoken style and a limited field of use. They are not codified, characterised by the spontaneity of the process of nomination, and rely on the results of perceptual cognition (bird - aircraft, Kick the Tires and Light the Fires - Shorten the pre-flight walk around, zoombag - flight suit, bogey - unidentified and potentially hostile aircraft, etc.).

In some cases, slang can fill the lacunae of concepts that do not have terms for their verbalisation. In the speech of professionals, slang can serve as an indicator of a high degree of involvement in the profession, its creative interpretation and comprehension. It is characterised by ethical-stylistic decline (low style), high degree of expression, and deviation from the norm.

\section{Conclusion}

This article studied basic characteristics of subject-specific vocabulary classes and presented authors' opinion on Aviation English vocabulary stratification. Subject-specific vocabulary is stated to define, form and transfer professional knowledge and is contrasted to general vocabulary. In-depth study of the linguistic papers indicated that terms, semi-technical vocabulary, professionalisms, professional slang and jargon, nomenclature names are the most often distinguished classes of specific language vocabulary. Based on the analysis of the lexical items from aviation dictionaries and their functioning in aviation documents, as well as 
articles and real speech acts we have stratified Aviation English vocabulary into basic aviation concepts, general scientific and interdisciplinary terms, semi-technical vocabulary, nomenclature names (nomens), codes and professional slang and jargon. Short descriptions and examples of corresponding lexical units of each group were presented. Authors of this article hope that the research can be a foundation for further linguistic analysis of aviation glossary items as well as be of value for Aviation English instructors in terms of constructing their syllabus on vocabulary teaching.

\section{References:}

Asmukovich, I.V. (2011) Strukturno-semantychna orhanizatsiia aviatsiynoyi termonologiyi anhliiskoyi movy [Structural-semantic organization of English aviation terminology]. Naukovi pratsi Kamianets-podilskoho universytetu imeni Ivana Ohiienka / Filologichni nauky, zbirnyk naukovyh prats, 15-18.

Baker, M. (1988). Sub-technical Vocabulary and the ESP Teacher: an Analysis of Some Rhetorical Items in Medical Journal Articles. Reading in a Foreign Language, 4(2), 91-105.

Bugaienko, N. P., \& Zhulikov, E. V. (2013). Semanticheskaya struktura terminov i vozmozhnyie kriterii ih otgranicheniya ot smezhnyh plastov leksiki [Semantic structure of terms and possible criteria of their differentiation from adjacent layers of lexis]. Almanah sovremennoi nauki i obrazovaniya, 5(72), 33-37.

Coxhead, A. (2017). Approaches and perspectives on teaching vocabulary for discipline-specific academic writing. In John Flowerdew, Tracey Costley (Ed.), Discipline-Specific Writing: Theory Into Practice (pp. 62-76). NY, NY: Routledge.

Dudley-Evans, T. \& St. John, M. J. (1998). Developments in ESP: A Multi-Disciplinary Approach. Edinburgh: Cambridge University Press.

Dyakov, A. S. Kyiak, T. R. Kudelko, Z. B. (2000). Osnovy terminotvorennya: semantychni ta sotsiolingvistychni aspekty [Basics of term creation: semantic and sociolinguistic aspects]. Kyiv, Ukraine: KM Academia.

Fraser, S. (2012). Factors Affecting the Learnability of Technical Vocabulary: Findings from a Specialized Corpus. Hiroshima Studies in Language and Language Education, 15, 123-142. https://doi.org//10.15027/32299

Glaser, R. (2000). Should LSP Dictionaries. also Include Professional Jargon and Slang? Lexikos, 10, 86-98. http://dx.doi.org/10.5788/10-0-888

Griniev, S. V. (1993). Vvedenie v terminovedenie (Introduction to terms study). Moscow, Russia: Moscow Lyceum.

Hudson, K. (1978). The Jargon of the Professions. London, UK: The MacMillan Press Ltd. https://doi.org/10.1007/978-1-349-03199-3

Hutchinson, T., \& Waters, A. (1987). English for specific purposes: a Learning- centered Approach. Cambridge: Cambridge. University Press.

Karaban, V. I. (2004). Pereklad angliyskoyi naukovoyi i tekhnichnoyi literatury [Translation of English scientific and technical literature]. Vinnytsya, Ukraine: Nova Knyha.

Kopecka, B. (2017). "Planes are Birds" Metaphor: A Cognitively Oriented Study of Aviation Vocabulary In Grygiel, M. (Ed.), Cognitive Approaches to Specialist Languages (pp. 202-213). Newcastle upon Tyne: Cambridge Scholars Publishing.

Moder, C. L. (2013). Aviation English In Paltridge, B., Starfield, S. (Eds.), The handbook of English for specific purposes (pp. $227-$ 242). Malden: Wiley Blackwell.

Mykhailova, T. V. (2001). Semantychni vidnoshennya v ukrayinskii naukovo-technichniy terminologoyi [Semantic relations in Ukraininan science-technical terminology]. Unpublished PhD dissertation. Kharkiv, Ukraine: KHNU im. V. Karazina.

Pavlova, O. I. (2008). Terminy, profesionalizmy ta nomenklaturni znaky (do problemy klasyfikatsiyi spetsialnoyi leksyky) [Terms, professionalisms and nomenclature names (on the problem of special vocabulary classification)]. Visnyk Natsionalnogo Universytety "Lvivska Politekhnika"/ Seriya "Problemy ukrayinskoyi terminologiyi", 620, 49-54.

Pearson, J. (1998). Terms in Context. Amsterdam, Netherlands: John Benjamins Publishing Company.

Rozental, D. E., \& Telenkova, M. A. (2001). Slovar-spravochnik lingvisticheskih terminov [Dictionary of lingustic term]. Moscow, Russia: OOO “Izd. Astrel”.

Serbinovskaya, N. V. (2009). Terminologicheskoe pole "Marketing” v russkom yazyke [Terminology field "Marketing” in the Russian language]. Novocherkassk, Russia: YURGTU (NPI).

Shelov, S. D., \& Leichik, V. M. (2012). O klassfikatsii professionalnoi leksiki [On professional lexis classification]. Izvestiya RAN, Seriya Literatury i Yazyka, 71(2), 3-16.

Tabanakova, V. D. (2013). Avtorskiy termin: znayu, interpretiruyu, perevozhu [Author's term: know, interpret, translate]. Tiumen, Russia: Izdatelstvo Tiumenskogo gosudarstvennogo universiteta.

Wang, A. (2011). A Methodological Probe to Aeronautical English Vocabulary Instruction. Open Journal of Modern Linguistics, $1(2), 45-51$. 